\title{
ENRICHING HUMAN-ROBOT INTERACTION WITH MOBILE APP IN INTERVENTIONS OF CHILDREN WITH AUTISM SPECTRUM DISORDER
}

\author{
Tatjana Zorcec ${ }^{1}$, Bojan Ilijoski ${ }^{2}$, Sanja Simlesa ${ }^{3}$, Nevena Ackovska ${ }^{2}$, Monika Rosandic ${ }^{3}$, \\ Klara Popcevic ${ }^{3}$, Ben Robins ${ }^{4}$, Noa Nitzan ${ }^{5}$, Dana Cappel $^{5}$, Rachel Blum ${ }^{5}$ \\ ${ }^{1}$ University Children's Hospital, Skopje, N Macedonia \\ ${ }^{2}$ Faculty of Computer Science and Engineering, Skopje, N Macedonia \\ ${ }^{3}$ Faculty of Education and Rehabilitation Sciences, Zagreb, Croatia \\ ${ }^{4}$ Univniversity of Hertfordshire, Hatfield, UK \\ ${ }^{5}$ Bet Issie Shapiro, Amutat Avi-Ra'anana, Israel
}

Corresponding author: Tatjana Zorcec, University Children's Hospital, Skopje, Macedonia, e-mail: tzorcec@gmail. com

\section{ABSTRACT}

Introduction: Autism spectrum disorder (ASD) is a group of complex lifelong neurodevelopmental disorders, characterized by difficulties in social communication and stereotyped behaviours. Due to the increasing number of children with ASD, it is important to continue developing interventions as well as invent new ones. Human-robot interaction can contribute to better outcomes for these children. There are several robots such as Nao, Kaspar, ZENO, Probo, ZECA, etc. which are used in autism interventions. Many mobile and web applications are in constant growth, too. They target skills such as collaboration, social skills, language skills, social competence, and communication.

Aim: To explore the usability of the humanoid robot Kaspar and a complementary app in interventions of children with ASD.

Sample: 20 children with ASD, aged between 23 and 76 months old.

Method: As an added intervention for this group of children, we used the robot Kaspar and its complementary app. Kaspar is a child-sized humanoid robot that uses bodily expressions, facial expressions, gestures, and pre-recorded speech to interact with a human.

Results: This intervention achieved certain positive shifts in eight of the eleven measured developmental domains, such as communication functions and means, turn taking, imitation, language skills, play, attention and daily life skills. The three categories that had inconsiderable improvement are vocalization and speech, cause and effect and coping skills.

Conclusion: Based on the measurements before and after the use of Kaspar and its complementary app, there is improvement, primarily in the domains of language, imitation and communication skills and attention.

Keywords: autism spectrum disorder, children, robot and mobile app intervention

\section{INTRODUCTION}

Autism spectrum disorder (ASD) is a group of complex lifelong neurodevelopmental disorders, characterized by difficulties in social communication and interaction and stereotyped behaviours. Due to the increasing number of children diagnosed with ASD over the last few decades [1], it is important to continue developing interventional methods and treatments for those 
children as well as invent new ones. Early interventions and treatments have been very important in helping children with ASD, and have provided better outcomes. There are several evidence-based approaches that help therapists and parents to achieve these goals: Applied Behavior Analysis uses rewards to reinforce positive behaviours and teach new skills, Training of Social Skills improves a child's interaction with society and the formation of bonds with others, Relationship Development Intervention Family-Centered Approach helps to treat autism, focusing on defined emotional and social objectives which are meant to establish more meaningful relationships; Picture Exchange Communication System is usually used to teach intentional, functional communication and to allow users to communicate their wants and needs; Technology-Aided Instruction and Intervention includes specifically designed technology to support the learning or performance of a behaviour or skill in different developmental domains [2-3]. Enriching the therapy process with different tools such as special sensors, mobile phones, tablets, robots, and other IT devices may raise the productivity level of therapy and contribute to better treatment outcomes [4-11].

Including human-robot interaction (HRI) in interventions for children with ASD can contribute significantly to the therapy process. There are several approaches that are currently using robots such as Nao, Kaspar, ZENO, Probo, ZECA, etc. in autism interventions [9-11]. All of them rely on one or multiple goals as "Modelling, teaching and, skills practicing", "Test, highlight and evaluate", "Provide feedback or encouragement", "Joint Attention", "Elicit social behaviours", "Emotion recognition and expression", "Imitation", "Vocalization", "Turn-taking", "Diagnostic", etc. According to these results, robotic therapy has brought about positive outcomes for individuals with ASD, and there have been several major improvements in the field of robot engineering and HRI. There is also great diversity in research focus and intervention effectiveness. There are several studies and pilot studies related to this methodology, many of which observe this process from different perspectives and different robots are used like Keepon, Kaspar, Nao, Alice [12-15] etc. These research papers conclude that, due to specific features, robots have proven effective in teaching children communication and social skills. Children with ASD are able to approach the robots with curiosity, and they feel safe because of the simplicity of the robot. Furthermore, they usually try to interact with the robot and share with others the pleasure they found [12]. The robots can also be used to trigger further interaction with other children [13]. The frequency and the duration of each interaction between the child and the robot play a crucial role in triggering a response. Also, it is important to keep all of the interactions simple and predictable in order to expose children with ASD to basic interactive activities [14]. We can therefore argue that HRI plays a significant role in the therapy of children with ASD. It can leverage the interest of the children in particular activities as well as being helpful to parents and practitioners to facilitate their roles and services. Studies show that participants are happy and eager to attend the interventions that are HRI supported [15]. These kinds of treatments also seem to be effective in different manifestations of ASD [16]. Usually, these treatments are implemented in some kind of play between the children and the robot. Due to their lack of playing skills in early childhood, the improvement of these skills is very important, thus increasing the motivation and pleasure of children with ASD. Furthermore, playing allows children to learn and practice new skills in a secure and trusted environment. Since the robots are fun to play with, they are promising tools in the therapy for children with ASD. Even if this area of research is still very young, it looks promising. It appears to be helping children with ASD to develop social skills and understand emotions $[4-8,17]$.

A number of mobile and web applications for children with ASD are in constant growth. They target skills such as collaboration, social skills, language skills, social competence, social communication, etc. Some of them even include artificial intelligence in order to enrich the applications, or they combine AI with other applications such as recognizing complex emotions and mental state recognition. Most of those applications are in the form of serious games whose main purpose is education and therapy. Most of the applications are desktop or laptop based, but there are also applications for tablets and mobile phones as well as consoles. As we mentioned before, there are several skills that these applications are trying to trigger, and more than half of them are related to social and communication skills. A quarter of these applications are related to improving conversation skills and communication therapy. There are other purposes such as sensory integration, imaginative skills, first aid, learning accounting, etc. From the aspect of user 
interaction, most of them rely on ordinary input and touch screens [18-19].

The main goal of this study is to explore the usability of the humanoid robot Kaspar and its complementary app in interventions of children with ASD. Since children with ASD are often already interested in apps [20] as well as robots, the main idea is to develop the process so that what children usually experience in a therapist's office will then be made available for home use. This will provide more time for children to interact with the robot, or in this case app as well.

\section{METHODOLOGY}

\section{Sample}

The sample consisted of 20 children, previously diagnosed with ASD. Eleven of them were living in Macedonia, already receiving regular treatment at the University Children's Hospital-Skopje and nine of them from Croatia, receiving regular treatment at the Faculty of Education and Rehabilitation Sciences-Zagreb. During this study, all children continued with the treatments they received before this study. All of them were between 23 and 76 months old $(\mathrm{M}=47.5 ; \mathrm{SD}=14.04)$. The duration of the study was 6 months, on average. Children in this group were non or minimally verbal to verbal, with low to high functioning forms of autism.

\section{Method and procedure}

In addition to existing treatments, for this group of children, we have added intervention with the use of the Kaspar robot at both sites (in

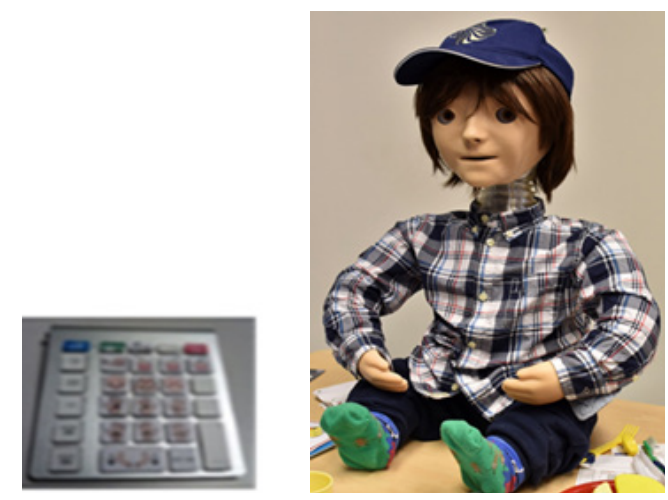

Fig. 1. The Kaspar robot (right); Wireless keypad for manual control (left)
Macedonia and Croatia), and utilized a complementary app for Kaspar, which was used in home settings. Kaspar is a child-sized humanoid robot that uses bodily expressions (movements of the head, arms, and torso), facial expressions, gestures and pre-recorded speech to interact with a human. Kaspar is a $60 \mathrm{~cm}$ tall robot that is fixed in a sitting position (Fig. 1).

Kaspar has been purposefully designed as a robot with simplified, realistic, human-like features. Kaspar offers a predictable form of communication, thereby making social interaction simpler, non-judgmental, and more comfortable for the child. As a three-dimensional physical object, it provides children with the opportunity for safe, physical engagement and exploration of Kaspar's features and behaviours in a non-judgmental manner. Kaspar's head can tilt, move from side to side, and up and down. Kaspar's face is made from a silicon rubber mask that covers a plastic frame and includes eyes that can move from side to side, as well as up and down, and eyelids that can open and shut. The mouth is capable of opening, smiling and portraying happy and sad expressions. In addition to all of the above features, Kaspar's torso can move from side to side. Kaspar is mounted with several touch sensors on cheeks, torso, left and right arm, back and palm of the hands, and also soles of the feet. These tactile sensing capabilities allow the robot to respond autonomously when being touched, allow it also to give feedback according to the style of the interaction, hence encouraging certain behaviours and discouraging inappropriate behaviour. The robot could also be operated by a remote controlled keypad which can be used by the accompanying adult, a therapist, or by the children themselves who interact with Kaspar. Kaspar can engage children with ASD in a variety of therapeutic/educational games such as turn-taking, joint attention and collaborative games, cause and effect games, etc. The robot can also hold objects (fork, spoon, toothbrush, comb, etc.) in order to play games where children can learn about food and hygiene, among other topics. Prior to its use, Kaspar was programmed with movements and speech phrases in the Macedonian and Croatian languages. Touching different robot parts causes different reactions and movements of the robot, and this setting was used in all other scenarios. Kaspar can react to the style of interaction with appropriate feedback and facial expressions. For example, a soft touch or tickling on the left foot will provoke robot to smile and say "this is nice, it 
tickles me", touch on the torso will provoke loud laugh, "ha, ha, ha", hitting or punching will cause the robot to have a 'sad' expression, turn the face and torso away to one side, cover the face with the hands and saying "ouch, this hurts".

In order to provide a safe environment where the child will feel comfortable, the study was designed to permit the children free interaction with Kaspar in a familiar room, in the presence of a parent and a mental health professional. The play scenarios included imitation games, learning emotions, turn taking games, learning animals and animal sounds, learning sounds and words, hygiene, and food.

Kaspar was placed on a table, connected to a laptop. The clinician was sitting next to the robot. The children were brought into the familiar room by their parents. If the child showed signs of anxiety or were not interested in any interaction, the sessions were interrupted. One video camera was recording the trials. Kaspar could respond autonomously to different tactile interactions, as well as be operated remotely via a wireless remote control (a specially programmed keypad), either by the clinician or by the child itself. Each trial lasted as long as the children were comfortable with staying in the room. The average duration of each trial was approximately 15 minutes.
The complementary app for Kaspar was created with all the scenarios used by the professionals during the intervention sessions. The idea was for the Kaspar app to be available for download and for use on any Android mobile device and PC web-based browser for children with ASD who were undergoing interventions with the Kaspar outside of intervention hours. The app consists of videos of the robot, which demonstrate the activities performed by the robot during the therapeutic sessions [21]. The videos presented are the bulk of the application and they occupy most of the screen. On the right part of the screen there are buttons for the activation of different robot activities. By pressing different buttons or playing different videos the robot executes different activities. The activities are divided into different categories such as songs, actions, food, animals, and body parts. On each button, in addition to the text that describes the activity, there is an image, aiding with easier recognition of the chosen activity. The images are the same as the activities in the original Kaspar control pads, which facilitates the work of people who have already had some experience working with Kaspar. This also helps children, since some of them have already used the Kaspar keypad. The app also provides two different modes, light and dark, for an improved user experience. The app allows the children, with the help of their parents,

Table 1. Significance of the difference between $A / L, \operatorname{Tr} / L, \operatorname{Tr} / T$ ond $L / T o$ ratios values of tissue and fat mass and their percentages in $C S, O$ and $C$

\begin{tabular}{|c|c|c|c|c|c|c|}
\hline Variable & CS & $\mathrm{O}_{1}$ & $\mathrm{O}_{2}$ & $\mathbf{C}$ & mean & $P$ - value \\
\hline $\mathrm{A} / \mathrm{L} \mathrm{T} \mathrm{gr}$ & $0.35 \pm 0.06$ & $0.23 \pm 0.04$ & $0.30 \pm 0.03$ & $0.18 \pm 0.02$ & $0.26 \pm 0.07$ & 0.0001 \\
\hline A/Legs F gr & $0.43 \pm 0.09$ & $0.23 \pm 0.07$ & $0.33 \pm 0.06$ & $0.14 \pm 0.04$ & $0.28 \pm 0.13$ & 0.0001 \\
\hline $\mathrm{A} / \mathrm{L}$ Tfat $\%$ & $1.23 \pm 0.19$ & $0.99 \pm 0.16$ & $1.12 \pm 0.15$ & $0.76 \pm 0.18$ & $1.03 \pm 0.24$ & 0.0001 \\
\hline A/Legs F\% & $1.27 \pm 0.20$ & $1.03 \pm 0.17$ & $1.15 \pm 0.16$ & $0.78 \pm 0.18$ & $1.06 \pm 0.25$ & 0.0001 \\
\hline Trunk/Legs T gr & $2.01 \pm 0.34$ & $1.43 \pm 0.20$ & $1.71 \pm 0.15$ & $1.28 \pm 0.13$ & $1.61 \pm 0.36$ & 0.0001 \\
\hline Trunk/Legs F gr & $2.31 \pm 0.53$ & $1.37 \pm 0.37$ & $1.84 \pm 0.35$ & $1.07 \pm 0.22$ & $1.65 \pm 0.60$ & 0.0001 \\
\hline Trunk/Legs Tfat $\%$ & $1.14 \pm 0.16$ & $0.95 \pm 0.13$ & $1.05 \pm 0.13$ & $0.83 \pm 0.11$ & $0.99 \pm 0.18$ & 0.0001 \\
\hline Trunk/Legs Fat\% & $1.17 \pm 0.17$ & $0.96 \pm 0.13$ & $1.07 \pm 0.13$ & $0.84 \pm 0.11$ & $1.01 \pm 0.18$ & 0.0001 \\
\hline $\operatorname{Tr} / \operatorname{To} \operatorname{Tgr}$ & $0.56 \pm 0.05$ & $0.49 \pm 0.03$ & $0.53 \pm 0.02$ & $0.47 \pm 0.02$ & $0.52 \pm 0.05$ & 0.0001 \\
\hline $\mathrm{Tr} / \mathrm{To} \mathrm{F}$ gr & $0.60 \pm 0.06$ & $0.50 \pm 0.05$ & $0.56 \pm 0.04$ & $0.45 \pm 0.04$ & $0.53 \pm 0.07$ & 0.0001 \\
\hline $\mathrm{Tr} / \mathrm{To} \mathrm{Tfat} \%$ & $1.07 \pm 0.06$ & $1.02 \pm 0.06$ & $1.05 \pm 0.04$ & $0.97 \pm 0.06$ & $1.03 \pm 0.07$ & 0.0001 \\
\hline Tr/To F\% & $1.09 \pm 0.062$ & $1.03 \pm 0.06$ & $1.06 \pm 0.043$ & $0.98 \pm 0.06$ & $1.04 \pm 0.07$ & 0.0001 \\
\hline L/To T gr & $0.28 \pm 0.03$ & $0.35 \pm 0.03$ & $0.31 \pm 0.02$ & $0.37 \pm 0.02$ & $0.33 \pm 0.04$ & 0.0001 \\
\hline L/To F gr & $0.27 \pm 0.05$ & $0.38 \pm 0.05$ & $0.31 \pm 0.03$ & $0.43 \pm 0.05$ & $0.35 \pm 0.08$ & 0.0001 \\
\hline L/To Tfat $\%$ & $0.95 \pm 0.08$ & $1.08 \pm 0.09$ & $1.00 \pm 0.07$ & $1.18 \pm 0.08$ & $1.05 \pm 0.12$ & 0.0001 \\
\hline L/To F\% & $0.94 \pm 0.08$ & $1.08 \pm .09$ & $0.94 \pm 0.10$ & $1.21 \pm 0.16$ & $1.04 \pm 0.16$ & 0.0001 \\
\hline
\end{tabular}


to work continuously with the robot as part of their treatment program. This approach fills the gap between sessions when they are at home.

Children of this group received interventions with Kaspar once or twice per week, and were instructed to use the app with the same or even greater frequency.

In order to evaluate the results from the combined intervention, we have created the following questionnaires:

- a parent questionnaire, with 65 questions, divided in 11 categories (table 1). The parent assesses a child's developmental domains pre and post use of Kaspar and its complementary app. All of the questions have five different answers: never, rarely, occasionally, frequently, and always, as well as n.a. for questions that are not applicable considering the child's behaviour and skills.

Table 1. Parent questionnaire and measured developmental domains

\begin{tabular}{|l|c|}
\hline Category & No. of questions \\
\hline $\begin{array}{l}\text { Communication functions and } \\
\text { means }\end{array}$ & 9 \\
\hline Gaze shift and eye contact & 4 \\
\hline Turn taking & 6 \\
\hline Imitation & 5 \\
\hline Language skills & 9 \\
\hline Vocalization and speech & 5 \\
\hline Cause and effect & 4 \\
\hline Play & 5 \\
\hline Attention & 4 \\
\hline Daily file skills & 8 \\
\hline Coping skills & 6 \\
\hline
\end{tabular}

- a questionnaire with 52 questions on the benefits/difficulties during the use of the complementary app in the home settings, in order to improve its features (qualitative exploration of satisfaction, positive and negative aspects, perceptions of appropriateness, barriers and facilitators of engagement, suggestions for improvement on any aspect of this approach).

\section{RESULTS AND DISCUSSION}

Out of 20 children in this group, 15 accepted and 5 did not accept interaction with the robot as the study wanted and planned. Those 5 children were upset during the sessions or outright ignoring them. Regarding the complementary app, 10 children were using and interacting with it, while 10 children refused to use the app or simply ignored it. Since the sessions with the robot were conducted by professionals in mental health and the app was used at in-home settings by the parents, it is possible that those children were not collaborating due to the subjective nature of child-parent interactions.

Measurements of developmental domains were analysed statistically with a paired sample t-test in order to discover possible significant differences between the two dependent variables: pre and post intervention. Therefore, we applied the Shapiro-Wilk test which informs us about how likely the data was drawn from a Gaussian distribution. According to the result of the Shapiro-Wilk test, the categories "Imitation", "Vocalization and speech", "Play", "Attention" and "Coping skills" most likely exhibit a normal distribution. For those variables, we applied paired samples, which are presented in table 2. The results show that we can reject the H0 hypothesis for "Imitation", "Play" and "Attention", which indicates that those variables have different mathematical means before and after the process. Therefore, we can conclude that there is an important gain in those categories. For "Vocalization and speech" and "Coping skills" we have $\mathrm{p}$ values greater than 0.05 , allowing us to accept $\mathrm{H} 0$ hypothesis, i.e. pairwise difference between the two categories is equal.

Table 2. Paired t-test for normally distributed measures of developmental domains

\begin{tabular}{|c|c|c|c|c|c|}
\hline 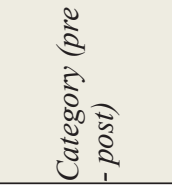 & $\frac{5}{3}$ & $\frac{\partial}{\stackrel{0}{0}}$ & $\begin{array}{l}\text { o̊ } \\
\text { ô } \\
\text { ô }\end{array}$ & w & 2 \\
\hline Imitation & -0.58 & 1.03 & {$[-1.06,-0.1]$} & -2.51 & 0.021 \\
\hline $\begin{array}{l}\text { Vocalization } \\
\text { and speech }\end{array}$ & -0.23 & 0.62 & {$[-0.52,0.06]$} & -1.65 & 0.12 \\
\hline Play & -0.58 & 0.8 & {$[-0.96,-0.2]$} & -3.22 & 0.004 \\
\hline Attention & -0.61 & 0.7 & $\begin{array}{l}{[-0.94} \\
-0.29]\end{array}$ & -3.94 & 0.001 \\
\hline $\begin{array}{l}\text { Coping } \\
\text { skills }\end{array}$ & -0.25 & 0.63 & {$[-0.55,0.05]$} & -1.76 & 0.094 \\
\hline
\end{tabular}

Because there are five categories that did not pass the assumption that they are normally distributed, we used a Wilcoxon signed-rank test. This test is usually used as an alternative to 
a paired $t$-test when we cannot assume that the distribution of the difference between two sam- ples' means is normally distributed. The results are presented in table 3 .

Table 3. Wilcoxon signed-rank test on measures of developmental domains

\begin{tabular}{|l|c|c|c|c|c|}
\hline Category (pre - post) & Mean & Std. Dev. & Median & W-wal & $p$ \\
\hline Communication functions and means & -0.59 & 0.75 & -0.278 & 3.5 & 0.001 \\
\hline Gaze shift and eye contact & -0.588 & 0.749 & -0.250 & 0.000 & 0.002 \\
\hline Turn taking & -0.425 & 0.832 & -0.167 & 17. & 0.05 \\
\hline Imitation & -0.58 & 1.034 & -0.5 & 29.5 & 0.026 \\
\hline Language skills & -0.683 & 0.721 & -0.444 & 1 & 0 \\
\hline Vocalization and speech & -0.23 & 0.623 & 0 & 27 & 0.195 \\
\hline Cause and effect & -0.263 & 1.226 & 0 & 35 & 0.271 \\
\hline Play & -0.58 & 0.805 & -0.3 & 7 & 0.004 \\
\hline Attention & -0.613 & 0.695 & -0.5 & 2 & 0.001 \\
\hline Daily life skills & -0.762 & 0.675 & -0.688 & 1 & 0.001 \\
\hline Coping skills & -0.25 & 0.634 & 0 & 26.5 & 0.102 \\
\hline
\end{tabular}

From the results of the Wilcoxon test we can see that for the following categories, "Communication functions and means", "Gaze shift and eye contact", "Turn taking", "Imitation", "Language skills", "Play", "Attention" and "Daily life skills", the median difference is not zero and we can reject the $\mathrm{H} 0$ hypothesis, meaning that there is a significant difference between the medians of the two samples. Also, if we check the difference between the mean and median for "Vocalization and speech", "Cause and effect", and "Coping skills", the mean difference is around -0.25 , and median difference is 0 . Therefore, there are no major shifts for these values. For the other categories the mean difference is smaller than -0.4 and median difference is smaller than -0.15 .

The results in Table 3 show that significant shifts have occurred in almost all developmental domains. Development areas where partial/symbolic progress has been achieved are "Vocalization and speech", "Cause and effect" and "Coping skills". If we observe, in detail, the scenarios that were conceived and implemented in the work with Kaspar and the app, we will notice that language skills, imitation skills and, to some extent, communication skills were encouraged the most. At the onset of the research project, both Kaspar and the accompanying app were supposed to encourage coping skills, cause and effect skills, and play and daily life skills, equally. However, due to the coronavirus pandemic and compliance with epidemiological guidelines, the duration of the session with the children was shortened from 30 to 15 minutes, and certain changes were made in the protocol. Kaspar and its app primarily encouraged the abilities in which the change ultimately took place. The results show that change has occurred in both the "Play" and "Daily life skills" domains. This can be explained as a secondary shift, occurring as a result of training sessions conducted by Kaspar and the app, or as part of a child's maturation. Kaspar mostly encouraged children's language comprehension by asking them to point at body parts, certain animals, different emotions, etc. If we look at the questionnaire, the change between the first and second measurements occurred in areas such as: "The child points to objects/animals in the picture book (e.g., a house, flower, dog, etc.) when asked", "The child follows simple instructions" (e.g., Come here, or Sit down, or Press the button); "The child uses words to express their own emotions "(e.g., I am happy, I am scared, etc.). Kaspar and the app also performed various actions that the child was supposed to imitate (for example: combing, brushing teeth, playing drums), and observing the results for the area of imitations, we noticed significant differences between the first and second measurements. These results were expected because the questionnaire included responses such as "The child spontaneously imitates simple motor actions (e.g., clapping hands, waving goodbye, etc.); the child engages in imitation when prompted", and Kaspar encouraged imitation skills such as combing, brushing teeth, waving goodbye and the like during sessions with the child. Communication skills also displayed differences before and after working with Kaspar and the app. These differences can be attributed to the fact that, during in- 
tervention, the child was often expected to ask for continued activities, to request certain objects, actions, to establish eye contact, to wave goodbye, to get involved in the activities of others which was all assessed in the questionnaire in the following domains: "Communication functions and means", "Gaze shift \& eye contact", "Turn taking". Also, we can see that, due to the work of the child with the robot Kaspar and the app, there were certain changes in the child's attention span (for example: "The child actively explores objects and events for more extended periods; The child is able to refocus concentration from one stimulus to another").

The results of the study showed that interventions with Kaspar and its complementary app in this group of children with ASD, achieved certain positive shifts in eight of eleven measured developmental domains, such as "Communication functions and means", "Turn taking", "Imitation", "Language skills", "Play", "Attention" and "Daily life skills". The three categories that had inconsiderable improvement are "Vocalization and speech", "Cause and effect" and "Coping skills". In our results, we notice shifts in "Play" and "Daily life skills" but we cannot explain this as a direct impact of the child's work with the robot Kaspar and the app, since those abilities were not significantly encouraged.

\section{CONCLUSIONS}

Based on the measurements, before and after the use of the robot and complementary app, there is an improvement in the children's skills and behaviour, primarily in the domain of language skills, imitation skills, communication skills, and attention.

Study results do not mean that the improvement is based just on the use of the robot and complementary app, since all children in this group undergo other treatments as well. However, according to the questionnaires and parents' responses, we can conclude that most of the children learned and improved via the use of the robot and its complementary app. Therefore, we find that the implementation of Kaspar in clinical use and its app in a home setting, for this group of children with ASD, is very promising and can be used with other children. Future research is planned.

\section{Limitations of the Study and Future Recom- mendations}

The current study is characterized by some limitations, especially regarding recruiting sample and some methodological issues. First, the children included in the intervention were already included in the therapy process at institutions where the research was conducted. Therefore, the criteria of choosing the participants were not defined in advance. Important information about the participants is not available, i.e. the cognitive status or language development level. These can be crucial characteristics which previous studies proved to be instrumental in the development of many domains we measured (communication functions and means, play, i.e.).

Also, we did not include the control group of children with ASD who did not attend treatment with Kaspar. As previously mentioned, we cannot be sure that a child's development in several domains is a direct result of the use of Kaspar more than just a maturation process or other related interventions.

This paper provides preliminary information on the use of robots and apps in the treatment of children with autism. In the future, we plan to reach out to a wider group of children, with whom we would apply this approach and maintain a control group of children. More scenarios would be ideally included in the application itself as well as more possibilities for its personalization.

\section{REFERENCES}

1. Chiarotti F, Venerosi A. Epidemiology of Autism Spectrum Disorders: A Review of Worldwide Prevalence Estimates Since 2014, Brain Sci. 2020; 10(5): 274.

2. Steinbrenner JR, Hume K, Odom SL, Morin KL, Nowell SW, Tomaszewski B, Szendrey S, McIntyre NS, Yücesoy-Özkan, Ş, Savage MN. Evidence-Based Practices for Children, Youth, and Young Adults with Autism. The University of North Carolina at Chapel Hill, Frank Porter Graham Child Development Institute, National Clearinghouse on Autism Evidence and Practice Review Team. 2020.

3. Randolph, MA. Findings and conclusions: National standards project, phase 2. National Autism Center. 2015.

4. Robins B. Dautenhahn K. Dubowski J. Robots as Isolators or Mediators for Children with Au- 
tism: A Cautionary Tale. Proceedings of AISB'05 Symposium on Robot Companions Hard Problems and Open Challenges in Human-Robot Interaction. 2005

5. Zorcec T, Robins B, Dautenhahn K. Getting Engaged: Assisted Play with a Humanoid Robot Kaspar for Children with Severe Autism. ICT Innovations Communications in Computer and Information Science. 2018, 940; 198-207.

6. Tanevska A, Ackovska N, Kirandziska V. Robot-assisted therapy: considering the social and ethical aspects when working with autistic children. 9th International Workshop on Human $\mathrm{Hu}-$ man Friendly Robotics. 2016

7. Ackovska N, Kirandziska V, Tanevska A, Bozinovska L, Bozinovski A. Robot - assisted therapy for autistic children. 2017; 1-2.

8. Dimitrievska V, Ackovska N. Behavior Models of Emotion-Featured Robots: A Survey. Journal of Intelligent \& Robotic Systems. 2020; 100.

9. Saleh MA, Hanapiah FA, Hashim H. Robot applications for autism: a comprehensive review. Disabil Rehabil Assist Technol. 2020; 24:1-23.

10. Ismail LI, Verhoeven T, Dambre J. Leveraging Robotics Research for Children with Autism: A Review. Int J of Soc Robotics. 2019; 11, 389410.

11. Begum M, Serna RW, Yanco HA. Are Robots Ready to Deliver Autism Interventions? A Comprehensive Review. Int J of Soc Robotics. 2016; 8: 157-181.

12. Kozima H, Nakagawa C, Yasuda Y. Interactive robots for communication-care: a case-study in autism therapy. IEEE International Workshop on Robot and Human Interactive Communication. 2005; 341-346.

13. Wainer J, Robins B, Amirabdollahian F, Dautenhahn K. Using the Humanoid Robot KASPAR to
Autonomously Play Triadic Games and Facilitate Collaborative Play Among Children With Autism. IEEE Transactions on Autonomous Mental. 2014; 6(3); 183-199.

14. Shamsuddin S. Initial response of autistic children in human-robot interaction therapy with humanoid robot NAO. IEEE 8th International Colloquium on Signal Processing and its Applications. 2012;188-193.

15. Ghorbandaei Pour A, Taheri A, Alemi M. Human-Robot Facial Expression Reciprocal Interaction Platform: Case Studies on Children with Autism. Int J of Soc Robotics. 2018; 10; 179198.

16. Taheri A, Meghdari A, Alemi M. Human-Robot Interaction in Autism Treatment: A Case Study on Three Pairs of Autistic Children as Twins, Siblings, and Classmates. Int J of Soc Robotics. 2018; 10; 93-113.

17. Dautenhahn K. Socially intelligent robots: dimensions of human-robot interactionPhil. Trans. R. Soc. 2007; B362679-704.

18. Chen W. Multitouch Tabletop Technology for People with Autism Spectrum Disorder: A Review of the Literature. Procedia Computer Science. 2012; 14: 198-207.

19. Zakari HM, Ma M, Simmons D. A Review of Serious Games for Children with Autism Spectrum Disorders (ASD). Lecture Notes in Computer Science. 2014; 93-106.

20. Munoz R, Mancilla F, Barcelos T, Chalegre V, Kreisel S. Development of Software that Supports the Improvement of the Empathy in Children with Autism Spectrum Disorder. Proceedings - International Conference of the Chilean Computer Science Society. 2012; 223-228.

21. https://smart.finki.ukim.mk (last visited: 30.5.2021) 


\title{
Резиме
}

\section{ЗБОГАТУВАЊЕ НА ИНТЕРАКЦИЈАТА ЧОВЕК - РОБОТ СО МОБИЛНА АПЛИКАЦИЈА ВО ИНТЕРВЕНЦИИТЕ НА ДЕЦА СО АУТИЗАМ}

\author{
Татјана Зорчец ${ }^{1}$ Бојан Илијоски ${ }^{1}$, Сања Шимлеша ${ }^{3}$, Невена Ацковска ${ }^{1}$, \\ Моника Росандиќ ${ }^{3}$, Клара Попчевиќ ${ }^{3}$, Бен Робинс ${ }^{4}$, Ноа Нитзан $^{5}$, Дана Капел ${ }^{5}$ Рахел Блум \\ ${ }^{1}$ Универзитетска Клиника за детски болести, Скопје, РС Македонија \\ ${ }^{2}$ Факултет за информатички науки и компјутерско инженерство, Скопје, РС Македонија \\ ${ }^{3}$ Факултет за едукациски и рехабилитаторски науки, Загреб, Хрватска \\ ${ }^{4}$ Универзитет од Хертфордшајер, Хатфилд, Хрватска \\ ${ }^{5}$ Бет Иси Шапиро, Амутат Ави-Раанана, Израел
}

Вовед: Растројствата од аутистичниот спектар (РАС) се група комплексни доживотни невроразвојни растројства, кои се карактеризираат со тешкотии во социјалната комуникација и стереотипни однесувања. Поради зголемениот број деца со РАС, битно е да се продолжи со развој на интервенциите, како и со креирање нови. Интеракцијата човек - робот може да придонесе за подобри резултати за овие деца. Засега во интрервенциите кај деца со аутизам се употребуваат неколку роботи, како што се Нао, Каспар, ЗЕНО, Пробо, ЗЕКА итн. Бројот на мобилни и веб-апликации, исто така, е во постојан раст. Тие се насочени кон подобрување на вештините, како соработка, социјални вештини, јазични вештини, социјална компетентност и комуникација.

Цел: Истражување на употребливоста на хуманоидниот робот Каспар и комплементарната апликација при интервенции кај деца со РАС.

Примерок: 20 деца со АCH, на возраст меѓу 23 и 76 месеци.

Метод: Како дополнителна интервенција за оваа група деца го користевме роботот Каспар и неговата комплементарна апликација. Каспар е хуманоиден робот со големина на дете, кој користи телесни и лицеви изрази, гестови и претходно снимен говор за да комуницира со детето.

Резултати: Оваа интервенција постигна одредени позитивни поместувања во осум од единаесет измерени развојни домени, како што се комуникациските функции и средства, активностите „,jac, па ти“, имитација, говор, игра, внимание и секојдневни животни вештини. Кај трите категории, вокализација и говор, причина и последица и вештини за справување, се забележа незначително подобрување.

Заклучок: Врз основа на мерењата пред и по употребата на Каспар и комплементарната апликација, се забележува подобрување, пред сѐ во домените на говорот, имитациските и комуникациските вештини и вниманието.

Клучни зборови: аутизам, деца, робот, интервенции со робот и мобилна апликација 